\title{
Significance of the quantitative measurement of the chr16: 51320015 integration site in hepatocytes of patients with chronic hepatitis B
}

\author{
PENG RUAN $^{1,2^{*}}$, XIUFANG DAI $^{1 *}$, ZEQUN SUN $^{1}$, CHUNFANG ZHOU $^{1}$ and FAN YANG ${ }^{2}$ \\ ${ }^{1}$ Department of Gastroenterology, Renmin Hospital, Hubei University of Medicine, Shiyan, Hubei 442000; \\ ${ }^{2}$ Department of Gastroenterology, Renmin Hospital of Wuhan University, Wuhan, Hubei 430060, P.R. China
}

Received November 12, 2014; Accepted July 29, 2015

DOI: $10.3892 / \mathrm{mmr} .2015 .4319$

\begin{abstract}
The present study reported the presence of a hepatitis B virus (HBV) major integration site (MIS) chr16:51320015 and discussed the significance of quantitative measurement of this site. A total of 30 hepatitis $\mathrm{B}$ e antigen ( $\mathrm{HBeAg}$ ) positive (+) and $30 \mathrm{HBeAg}$ negative (-) patients with chronic hepatitis B (CHB) were enrolled in the present study, and the levels of intrahepatic (IH) covalently closed circular DNA (cccDNA), serum HBV DNA and hepatitis B surface antigen (HBsAg) were detected. Conventional reverse transcription-quantitative polymerase chain reaction (RT-qPCR) and Sanger sequencing were designed to verify the chr16:51320015 integration site, and the copy numbers of this site were measured using molecular clone and SYBR Green I RT-qPCR. This site was found to be present in the hepatocytes of all the enrolled patients, and the average number of copies was $1.46 \times 10^{-2} \pm 4.94 \times 10^{-2}$ copies/cell $\left(3.48 \times 10^{-5}-0.212\right.$ copies/cell). No significant difference in the copy numbers of this site were observed between the $\mathrm{HBeAg}(+)$ $\left(1.43 \pm 9.79 \times 10^{-1}\right.$ copies/cell) and HBeAg (-) patients $\left(6.58 \times 10^{-2} \pm 2.47 \times 10^{-2}\right.$ copies/cell; $\left.\mathrm{P}>0.05\right)$, which were positively correlated with the levels of serum HBsAg ( $\mathrm{P}=0.0038)$, but were not correlated with the levels of IH cccDNA $(\mathrm{P}=0.7785)$. In conclusion, the chr16:51320015 integration site may be a novel site, which persists in a several patients with HBV infection, and may accumulate in the hepatocytes due to clonal expansion. The diagnostic and therapeutic values of this site require further investigation.
\end{abstract}

Correspondence to: Dr Peng Ruan, Department of Gastroenterology, Renmin Hospital of Wuhan University, 238 Jiefang Road, Wuhan, Hubei 430060, P.R. China

E-mail: ruanpeng-1973@163.com

*Contributed equally

Key words: hepatitis B virus, HBV integration, chronic hepatitis B, covalently closed circular DNA, hepatitis B surface antigen

\section{Introduction}

In total, $400,000,000$ individuals are infected by hepatitis B virus (HBV) worldwide, which is a leading risk factor for hepatocellular carcinoma (HCC). During the process of HBV infection, certain HBV DNA molecules may enter the nuclei and integrate into the host chromosomal DNA, which is suspected to be one of the major etiological events in $\mathrm{HBV}$-induced HCC. Conventional polymerase chain reaction (PCR)-based methods, including Alu-PCR and inverse PCR, have technological limitations in detecting the presence of viral integration, resulting in only a small subset of insertions, or only the insertions close to the targeted human or viral sequences being efficiently detected (1-3). As a result, few HBV integration breakpoints have been found through these methods, and these findings may be of little oncogenic annotation.

With the rapid development of parallel sequencing technology, whole genome sequencing (WGS) has provided novel insight into $\mathrm{HBV}$ integration breakpoints in the HCC genome. Recently, through the application of WGS, several studies have reported a substantial number of unbiased and unprecedented HBV integrations, and a few frequently targeted genes in HCC including hTERT, MLL4 and CCNE1, have been identified simultaneously $(4,5)$. According to a previous study using WGS (6), the major integration site (MIS) (3), chr16: 51320015, was identified, and the present study aimed to detect the presence of this site in the hepatocytes of patients infected with chronic hepatitis B (CHB). Furthermore, the present study aimed to examine the significance of quantitative measurements of chr16:51320015 in these patients.

\section{Patients and methods}

Patients and samples. In the present study, 30 hepatitis B e antigen (HBeAg)-positive (+) and $30 \mathrm{HBeAg-negative} \mathrm{(-)}$ patients with $\mathrm{CHB}$ were recruited from the Department of Infectious Diseases, Remin Hospital, Hubei University of Medicine (Shiyan, China). CHB was documented by the presence of HBV DNA in the serum for $>6$ months and a serum alanine aminotransferase level greater than twice the normal range (7). All patients were treatment-naive. Patients who were 
co-infected with hepatitis D, hepatitis C or human immunodeficiency virus, or those with Wilson's disease, primary biliary cirrhosis or with a substantial daily alcohol intake (20 g/day for females; $30 \mathrm{~g} /$ day for males) were excluded from the investigation. Each patient signed an informed consent document and the study was approved by the Ethics Committee of Remin Hospital. Following collection, liver biopsy specimens $(\sim 10 \mathrm{mg})$ were frozen in liquid nitrogen and stored at $-80^{\circ} \mathrm{C}$, serum were stored at $-30^{\circ} \mathrm{C}$, respectively, until experimental analysis.

IH HBV covalently closed circular DNA (cccDNA) quantification. DNA was extracted from biopsy specimens using a QIAamp ${ }^{\circledR}$ DNA Mini kit (Qiagen, Hilden, Germany). The levels of intrahepatic (IH) covalently closed circular DNA (cccDNA) were measured using reverse transcription-quantitative (RT-q)PCR analysis, as described previously (8). $\beta$-globin DNA (housekeeping gene) was detected using a LightCycler ${ }^{\circledR}$ Control kit DNA (Roche Diagnostics GmbH, Mannheim, Germany) in order to count the cell number in the biopsies and calculate the number of copies/cell.

Serum HBV DNA quantification. DNA was extracted from $200 \mu$ serum using a QIAamp ${ }^{\circledR}$ DNA Blood Mini kit (Qiagen), and serum HBV DNA levels were measured using Cobas ${ }^{\circledR}$ TaqMan ${ }^{\circledR}$ RT-qPCR, as described previously (Roche Diagnostics) (9).

Quantification of serum hepatitis B surface antigen (HBsAg). The levels of HBsAg were quantified using an enzyme immunoassay with the Abbott ARCHITECT platform (Abbott Laboratories, Abbott Park, IL, USA), according to the manufacturer's instructions. HBsAg $>0.05 \mathrm{IU} / \mathrm{ml}$ was considered to indicate a positive result.

PCR and Sanger sequencing validation. Conventional PCR and Sanger sequencing were used to verify the chr16: 51320015 integration site in the hepatocytes of the patients. PCR primers for a 305 bp fragment were designed based on WGS-assembled sequences, in which one primer located in human genome and the other in HBV genome (forward 5'-GTCTTGCCCAAGGTCTTA-3' and reverse 5'-CAGATGGCGCACTAACAA-3'). The PCR mix was prepared as follows: $1 \mu \mathrm{l}$ DNA; $2 \mu \mathrm{l}$ 10xTaq Buffer; $11.5 \mu \mathrm{l}$ $\mathrm{H}_{2} \mathrm{O} ; 2.5 \mu \mathrm{l}$ dNTPs; $1 \mu \mathrm{l}$ forward and reverse primers $(10 \mu \mathrm{M}$, respectively); $1 \mu 1$ hot start Taq $^{\mathrm{TM}}$ enzyme (Takara Bio, Inc., Otsu, Japan). The following cycling conditions were used: Initial denaturation for $30 \mathrm{sec}$ at $95^{\circ} \mathrm{C}$; 40 cycles of denaturation for $10 \mathrm{sec}$ at $95^{\circ} \mathrm{C}$, annealing for $10 \mathrm{sec}$ at $56^{\circ} \mathrm{C}$ and extension for $14 \mathrm{sec}$ at $72^{\circ} \mathrm{C}$, final extension for $7 \mathrm{~min}$ at $72^{\circ} \mathrm{C}$. The PCR products were electrophoresed through a $1 \%$ agarose gel, and then extracted and sequenced using Sanger sequencing (Shanghai Sangon Biology Engineering Technology and Service Co, Ltd., Shanghai, China). Finally the results of the sequencing were compared with $\mathrm{HBV}$ and the human genome using the Basic Local Alignment Search Tool (BLAST; http:// blast.ncbi.nlm.nih.gov/Blast.cgi\#alnHdr).

Quantification of the chrl6: 51320015 integration site. The PCR-amplified fragment of the chr16: 51320015 integra- tion site was retrieved from the $1 \%$ agarose gels (Biowest LLC, Kansas City, MO, USA) with $0.5 \mu \mathrm{g} / \mathrm{ml}$ ethidium bromide (Promega Corporation, Madison, WI, USA) using a QIAquick Gel Extraction kit (Qiagen) and inserted into a PMD 18-T vector (Takara Bio, Inc.), which was electrotransformed into Escherichia coli DH5a cells (Takara Bio, Inc.) successively, according to the manufacturer's instructions. Following proliferation in lysogeny broth culture medium containing $100 \mu \mathrm{g} / \mathrm{ml}$ Ampicillin at $37^{\circ} \mathrm{C}$ for $16 \mathrm{~h}$ and blue-white screening, the fragment containing the plasmid was extracted using a QIAfilter Plasmid Mini kit (Qiagen) and quantified using nanodrop 2000 spectrophotometry (Thermo Fisher Scientific, Waltham, MA, USA) at $260 \mathrm{~nm}$. A series of quantification standards were made by diluting the plasmid in double distilled water. The standard dilutions were $5 \times 10^{7}, 5 \times 10^{5}, 5 \times 10^{4}, 5 \times 10^{3}$ and $5 \times 10^{2}$ copies/cell. Consequently, a $20 \mu \mathrm{l}$ reaction volume was used, containing $1 \mu 1$ extracted DNA, $0.8 \mu 1$ of the above-mentioned forward and reverse primers $(10 \mu \mathrm{M}), 7.4 \mu \mathrm{l}$ nuclease-free water and $10 \mu 12 X$ SYBR Green-I (Takara Bio, Inc.). SYBR Green I RT-qPCR was performed using a LightCycler ${ }^{\mathrm{TM}}$ (Roche Diagnostics), and the fluorescence was determined at $72^{\circ} \mathrm{C}$. According to the measurement of $\beta$-globin DNA, the numbers of chr16: 51320015 integration sites were detected and were compared as the number of copies/cell.

Statistical analysis. Statistical analyses were performed using SPSS 13.0 statistical software (SPSS, Inc., Chicago, IL, USA). Continuous variables are expressed as the mean \pm standard error of the mean and were analyzed using non-paired Student's t-tests. The levels of serum HBsAg (IU/ml) and HBV DNA (copies $/ \mathrm{ml}$ ) were logarithmically transformed prior to analysis. Categorical variables were compared using Pearson's $\chi^{2}$ test. Correlations were analyzed using Pearson's correlation coefficient. Two-sided $\mathrm{P}<0.05$ was considered to indicate a statistically significant difference.

\section{Results}

Baseline characteristics. The clinical, virological and serological characteristics of the patient groups used in the present study are listed in Table I. The HBeAg (+) patients, comprising 26 males and four females) were aged between 12 and 59 years (35.4 \pm 7.4 years), and the HBeAg (-) patients (23 males and seven females) were aged between 13 and 51 years (31.6 \pm 6.8 years; $\mathrm{P}>0.05)$. Serum HBV DNA levels were significantly lower in the HBeAg (-) patients, compared with those in the $\mathrm{HBeAg}$ $(+)$ patients $(\mathrm{P}=0.001)$, and the serum levels of HBsAg in the HBeAg (-) patients were lower than those in the HBeAg (+) patients, although this was not a statistically significant difference $(\mathrm{P}>0.05)$.

IH cccDNA quantification. The lower limit of detection for IH cccDNA was $2.4 \times 10^{-4}$ copies/cell. The levels of IH cccDNA were detectable in 26 of the HBeAg (-) patients and in all 30 of the $\mathrm{HBeAg}(+)$ patients enrolled in the present study, and the number of copies was significantly higher in the HBeAg (+) patients $\left(1.43 \pm 9.79 \times 10^{-1}\right.$ copies/cell), compared with the HBeAg $(-)$ patients $\left(6.58 \times 10^{-2} \pm 2.47 \times 10^{-2}\right.$ copies/cell; $\mathrm{P}<0.0001$; Fig. 1). 
Table I. Clinical, virological and serological parameters of HBeAg positive (+) patients and HBeAg negative (-) patients.

\begin{tabular}{lccc}
\hline Parameter & HBeAg $(+)$ & HBeAg $(-)$ & P-value \\
\hline Age $($ years $)$ & $35.42(12-59)$ & $31.64(13-51)$ & 0.171 \\
Gender $(\mathrm{M} / \mathrm{F})$ & $26 / 4$ & $23 / 7$ & 0.317 \\
HBsAg $\left(\log _{10} \mathrm{IU} / \mathrm{ml}\right)$ & $2.70(-1.15-4.27)$ & $1.66(-2-4.58)$ & 0.060 \\
HBV DNA $\left(\log _{10}\right.$ copies/ml $)$ & $5.45(2.71-8.13)$ & $4.10(2.43-5.29)$ & 0.001
\end{tabular}

Data are presented as $\mathrm{n}$ or the mean (range). HBV, hepatitis B virus; HBsAg, hepatitis B surface antigen; HBeAg, hepatitis B e antigen; M, male; F, female. ${ }^{a}$ Non-paired Student's $t$-test. ${ }^{b} x^{2}$ test.

A

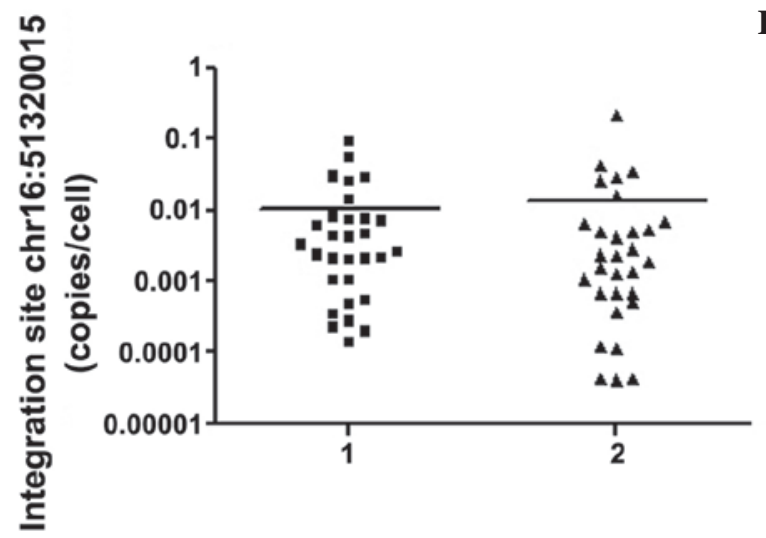

B

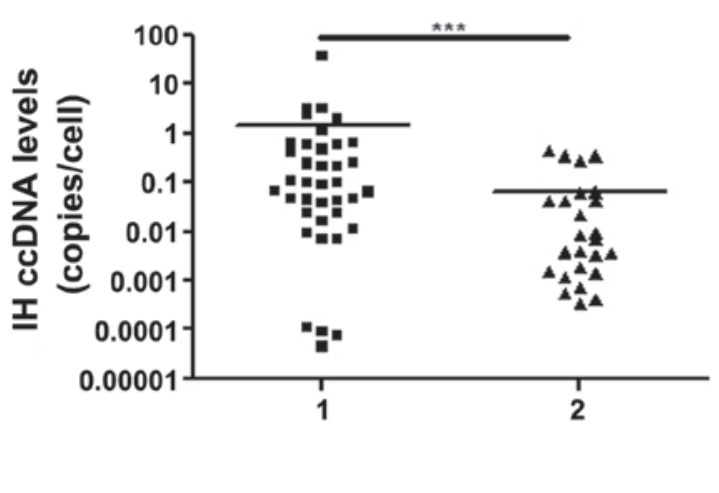

Figure 1. Copy numbers of the (A) chr16: 51320015 integration site and (B) levels of IH cccDNA in one hepatocyte from patients with CHB. Group 1, HBeAg+patients; group 2, HBeAg-patients. ${ }^{* * *} \mathrm{P}<0.001$. CHB; chronic hepatitis B; IH, intrahepatic; cccDNA, covalently closed circular DNA.

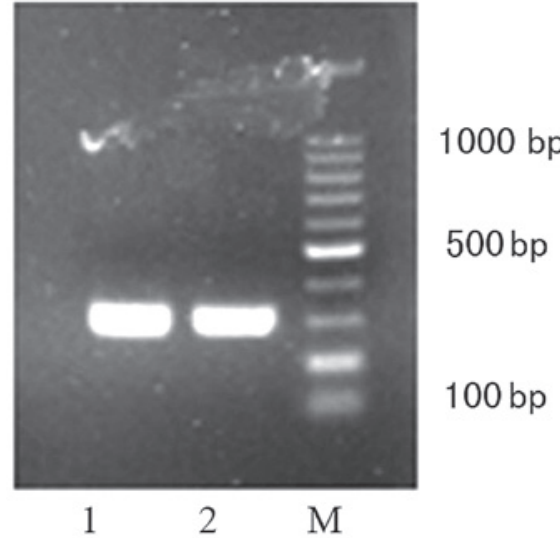

Figure 2. Chimeric fragment of the Chr16: 51320015 integration site (305 bp), 1, HBeAg+patients; 2, HBeAg-patients; M, DNA Marker (DL 100 bp).

Quantification of the chr16: 51320015 integration site. According to the results of the conventional RT-qPCR and Sanger sequencing, the chr16: 51320015 integration site was present in the hepatocytes of all the patients enrolled in the presents study, the fragments of which were located in the 1,631-1,807 nt of the HBV sequence and the $51,320,015-51,319,900 \mathrm{nt}$ of the human sequence, respectively (Figs. 2 and 3). The average level of this site was $1.21 \times 10^{-2} \pm 3.07 \times 10^{-2}$ copies/cell $\left(4.16 \times 10^{-5}-0.212\right.$ copies/cell). No significant difference was observed between The HBeAg (+) patients $\left(1.05 \times 10^{-2} \pm 3.60 \times 10^{-3}\right.$ copies/cell $)$ and the
HBeAg (-) patients $\left(1.37 \times 10^{-2} \pm 7.14 \times 10^{-3}\right.$ copies/cell; $\mathrm{P}>0.05$; Fig. 1).

Correlation analysis. The number of copies of the chr16: 51320015 integration site were positively correlated with the serum levels of HBsAg $(\mathrm{P}=0.0038)$, but not with the serum levels of HBV DNA or IH cccDNA ( $\mathrm{P}=0.7041$ and $\mathrm{P}=0.7785$, respectively). A weak correlation was observed between the levels of IH cccDNA and the serum levels of HBsAg $(\mathrm{P}=0.0048$; Fig. 4).

\section{Discussion}

Following the process of early or persistent HBV infection, relaxed-circle DNA ( $\mathrm{rcDNA}$ ) is transferred to the nucleus of hepatocytes, where it forms cccDNA, the virus transcriptional template $(10,11)$. Within infected cells, pregenomic RNA and is then transcribed from the cccDNA and is transported to the cytoplasm, where the mature capsids of the rcDNA are reverse transcribed and either secreted from the cells or returned to the nucleus to form the cccDNA pool. During the formation of cccDNA, linear HBV DNA, including double linear DNA and single-stranded DNA, produced through illegitimate replication and deficient HBV transcription, may integrate into the host chromosomal DNA (12). According to previous studies involving the application of WGS $(13,14)$, at least two promulgated mechanisms may be involved in the oncogenicity of HBV integration: (i) HBV DNA insertion into the host genome altering the function of endogenous genes, 


\section{CCAGGTCTTGCCCAAGGTCTTATATAAGAGGACTCTTGGACTCTCAGCAATGTCAACGAC 60 bp CGACCTTGATGCATACTTCAAAGACTGTTTGTTTAAGGACTGGGAGGAGTTGGGGGAGG 120 bp AGATTAGGTTAATGATCTTTGTACTTGGAGGCTGTAGGCATAAATTGGTCTGTTCACCCAA 180 bp AGTGGGATGTCTTTCCCAGGTACCGAAGGAGGAGAAACGCGTTATTTTGGCACACAATC 240 bp AGCCTTGGTCAATCAAGCCTTCAAGATCAGCCCATAATATGAGGACGTTGTTAGTGCGCC 300 bp ATCTGT}

Figure 3. Flanking sequence of the hepatitis B virus Chr16: 51320015 integration site. Red indicates the viral sequence (1,631-1,807 nt) and black indicates the human sequence $(51,320,015-51,3199,00 \mathrm{nt})$.
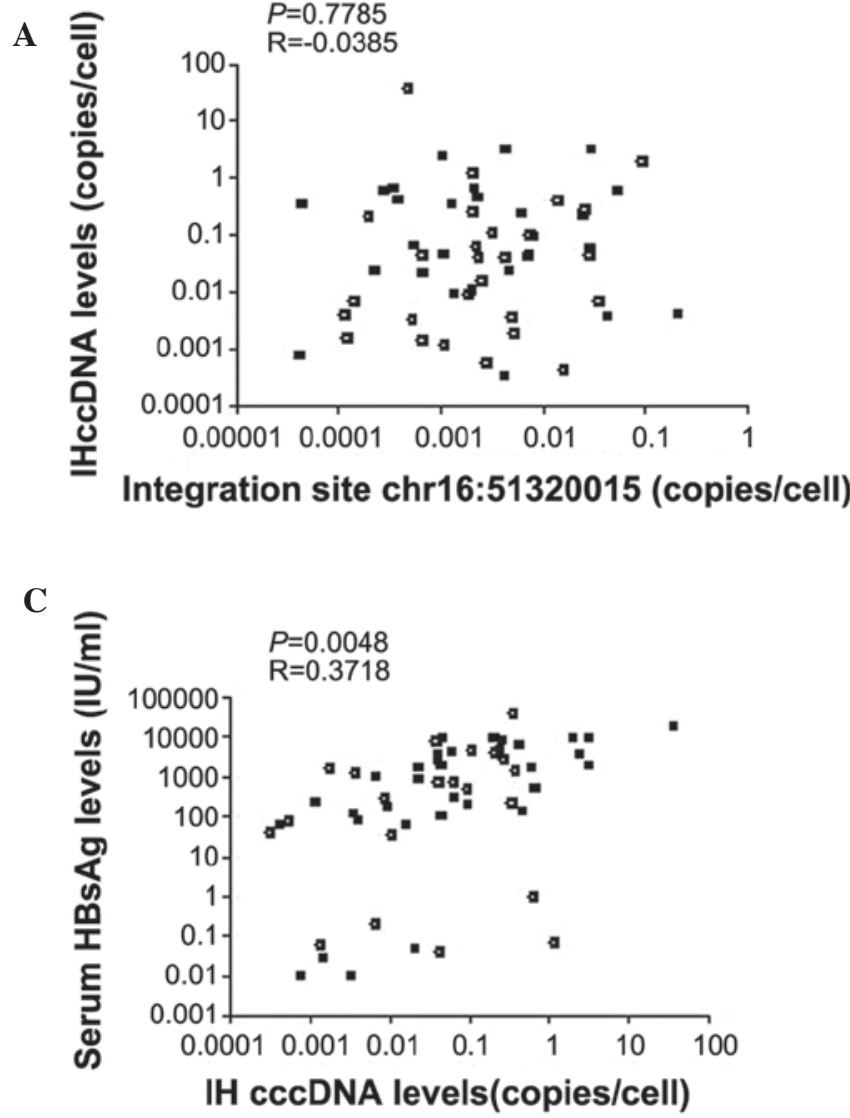

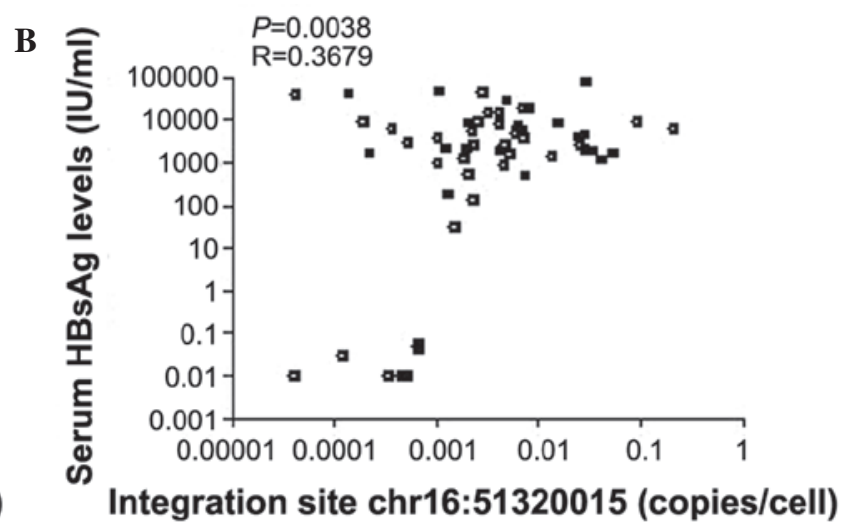

D

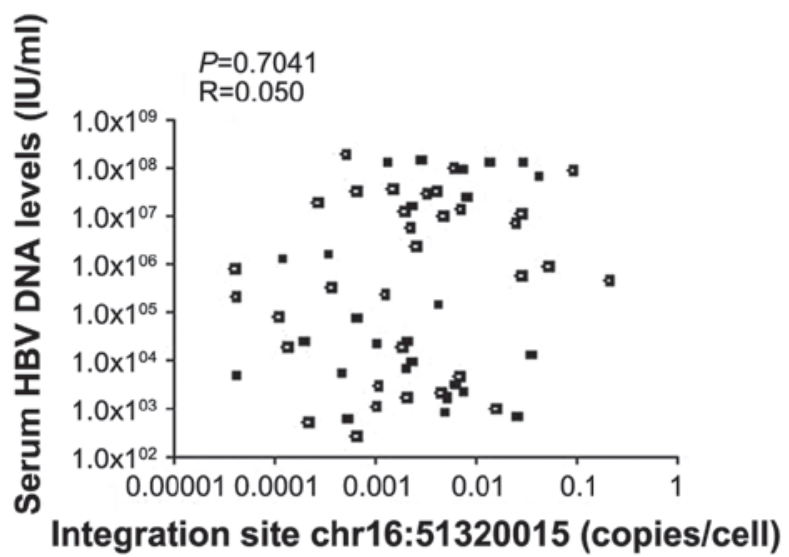

Figure 4. Correlation analysis between the (A) copy numbers of the chr16: 51320015 integration site and levels of IH cccDNA. (B) Copy numbers of the chr16:51320015 integration site and serum levels of HBsAg. (C) Levels of IH cccDNA and serum HBsAg, and (D) copy numbers of the chr16: 51320015 integration site and serum levels of HBV DNA. HBV, hepatitis B virus; IH, intrahepatic; cccDNA, covalently closed circular DNA; HBsAg, hepatitis B surface antigen.

and inducing chromosomal instability and changes in copy numbers; (ii) expression of C-terminal truncated HBx or HBs protein, which may modulate cell proliferation and viability. In addition, the immune response against virally-infected cells may be induced by the protein transcribed from integrated DNA, for example, the $\mathrm{x}$ gene. Thus, it is very important to effectively recognize and eradicate hepatocytes with integrated DNA in the treatment of CHB (6).

Early reports stated that HBV integration events may be randomly distributed across the whole genome $(2,3)$. However, increasing evidence has indicated that several genes may be preferentially integrated by the viral DNA, for example, chromosomes 10 and $17(5,6)$. The present study demonstrated that chr16: 51320015 may also be favorably integrated, and this junction was found to occrr in the hepatocytes of all the patients with $\mathrm{CHB}$ enrolled in the present study. The junction of its inserted viral fragment was at $1,807 \mathrm{nt}$, within the DR2-DR1 region of the HBV genome (1,590-1,834 nt). The DR2 and DR1 sites represent the ends of the partially duplex HBV DNA and can provide DNA termini for non-homologous end joining (NHEJ). Consequently these sites are more likely to be the initiation break points for HBV integration (15). However, in human chromatin HBV, integration events are more likely to occur in regions which are characterized by either looser secondary structures or open chromatin configuration, which facilitate breakage and provide DNA termini for NHEJ with HBV DNA (16). At present, it is difficult to recognize and eradicate hepatocytes with viral integration of 
patients with $\mathrm{CHB}$, however, the above findings may provide a novel perspective on either the diagnostic or therapeutic strategies of HBV integration, for example, chimeric antigen receptor therapy (17-19).

The liver is a closed, self-renewing population of cells, in which hepatocytes are generally long lived with a lifetime reported to exceed 6 months (20). During chronic HBV infection, hepatocyte transformation usually results from mutations that are caused by persistent inflammation, leading to cumulative oxidative damage to the host DNA (21). In addition, this environment provides the opportunity for the expansion of hepatocyte variants with a selective advantage, either in growth or survival (22). Although the basis of the clonal expansion in the hepatocytes remains to be fully elucidated, there are several explanations (23). A possible explanation involves cellular transformation leading to unregulated growth, however, this does not explain clones with no clear morphological transformation. A second explanation involves random death and regeneration within the entire hepatocyte population, however, is unlikely to explain the occurrence of very large clones of $>10^{4}$ hepatocytes. Another explanation for large clones of hepatocytes involves the resident stem/progenitor cells, however, this is not supported by the current knowledge (23). Finally, a model in which immune evasion caused by HBV integration is the basis for clonal expansions is favored, as although smaller cell clones may be the result of random turnover, the presence of copy clones of $>10^{5}$ cells requires alternative explanations (24).

Although HBV integration occurs at random sites in host DNA, and each integration event provides a unique genetic marker for the cells in which it occurred, the unique viral-cell junctions of integrated DNA may be used to track clonal proliferation of hepatocytes (22). Traditionally, clonal expansion was detected by assaying for integrated HBV DNA using inverse PCR. However, the level of clonal expansion may be underestimated using this technique, which is only suitable for detecting the integration of viral DNA close to particular restriction endonuclease cleavage sites in host DNA, and not all integrations can be detected using only a single enzyme (24). Thus, the present study aimed to investigate the clonal expansion of hepatocytes using quantitative measurements of the chr16: 51320015 integration site. The average level of this site was determined to be $1.21 \times 10^{-2} \pm 3.07 \times 10^{-2}$ copies/cell $\left(4.16 \times 10^{-5}-0.212\right.$ copies/cell), indicating that this integration site may have originated from clonal expansion, while high-copy clones with detectable integrated DNA have been estimated at a frequency of $>2 \times 10^{-6}$ copies/cell (22).

According to quantitative measurements of serum $\mathrm{HBeAg}$, patients with $\mathrm{CHB}$ can be divided into $\mathrm{HBeAg}(+)$ patients and $\mathrm{HBeAg}(-)$ patients, and $\mathrm{HBeAg}$ seroconversion and loss usually signify that HBV replication has been effectively suppressed by the host immunity (25). However, in the present study, although the levels of IH cccDNA and serum HBV DNA were significantly higher in the $\mathrm{HBeAg}(+)$ patients, compared with those in the $\mathrm{HBeAg}(-)$ patients, no significant differences in the number of copies of the chr16: 51320015 integration site and serum levels of HBsAg were found between the two patient groups. The copy numbers of chr16: 51320015 integration site were positively correlated with serum levels of HBsAg, but not with the levels of IH cccDNA. These findings may be due to the different origins of IH cccDNA and HBV integration. While the accumulation of IH cccDNA may be due to rcDNA recurrently entering into the nucleus, those of the chr16: 51320015 integration site, as described above, may have originated from the clonal expansion of integrated hepatocytes. Furthermore, the production of $\mathrm{HBsAg}$ in the $\mathrm{HBeAg}(-)$ patients, which is independent of HBV replication, was abundant and far exceeded that required for virion assembly. This may be partially produced from HBV integration (26-28), explaining the significant association between the copy numbers of the chr16: 51320015 integration site and serum levels of HBsAg, but weak association with the levels of IH cccDNA. Consequently, the present study hypothesized that, in patients with $\mathrm{CHB}$, the accumulation of HBV integration may not be effectively suppressed, even when the production of $\mathrm{HBV}$ is completely controlled by host immunity. These findings are in agreement with the hypothesis that, in addition to severe liver damage, HBV integration may also be a prerequisite for HCC (29).

In conclusion, the present study demonstrated that the chr16: 51320015 integration site was present in the hepatocytes of all the patients with $\mathrm{CHB}$, which may have accumulated according to clonal expansion. In addition, the number of copies of this site were positively correlated with the serum levels of HBsAg, but not with the levels of IH cccDNA. Whether this integration site occurs in the hepatocytes of all patients infected with HBV requires further investigation, as does its mechanism. In addition, whether or not hepatocytes with $\mathrm{HBV}$ integration can be effectively recognized and eradicated by means of this integration site requires elucidation.

\section{Acknowledgements}

This study was supported by grants from the National Natural Science Foundation of Hubei Province (grant no. 2015CFB290).

\section{References}

1. Murakami Y, Saigo K, Takashima H, Minami M, Okanoue T, Bréchot $\mathrm{C}$ and Paterlini-Bréchot $\mathrm{P}$ : Large scaled analysis of hepatitis B virus (HBV) DNA integration in HBV related hepatocellular carcinomas. Gut 54: 1162-1168, 2005.

2. Saigo K, Yoshida K, Ikeda R, Sakamoto Y, Murakami Y, Urashima T, Asano T, Kenmochi T and Inoue I: Integration of hepatitis B virus DNA into the myeloidl/ymphoid or mixed-lineage leukemia (MLL4) gene and rearrangements of MLL4 in human hepatocellular carcinoma. Hum Mutat 29: 703-708, 2008

3. Murakami Y, Minami M, Daimon Y and Okanoue T: Hepatitis B virus DNA in liver, serum and peripheral blood mononuclear cells after the clearance of serum hepatitis B virus surface antigen. J Med Virol 72: 203-214, 2004.

4. Jiang Z, Jhunjhunwala S, Liu J, Haverty PM, Kennemer MI, Guan Y, Lee W, Carnevali P, Stinson J, Johnson S, et al: The effects of hepatitis B virus integration into the genomes of hepatocellular carcinoma patients. Genome Res 22: 593-601, 2012.

5. Sung WK, Zheng H, Li S, Chen R, Liu X, Li Y, Lee NP, Lee WH, Ariyaratne PN, Tennakoon C, et al: Genome-wide survey of recurrent HBV integration in hepatocellular carcinoma. Nat Genet 44: 765-769, 2012. 
6. Toh ST, Jin Y, Liu L, Wang J, Babrzadeh F, Gharizadeh B, Ronaghi M, Toh HC, Chow PK, Chung AY, et al: Deep sequencing of the hepatitis B virus in hepatocellular carcinoma patients reveals enriched integration events, structural alterations and sequence variations. Carcinogenesis 34: 787-798, 2013.

7. Chinese Society of Hepatology and Chinese Society of Infectious Diseases; Chinese Medical Association: The guideline of prevention and treatment for chronic hepatitis B (2010 version). Zhonghua Gan Zang Bing Za Zhi 19: 13-24, 2011 (In Chinese).

8. Bowden S, Jackson K, Littlejohn M and Locarnini S Quantification of HBV covalently closed circular DNA from liver tissue by real-time PCR. Methods Mol Med 95: 41-50, 2004

9. Weinberger KM, Wiedenmann E, Böhm S and Jilg W: Sensitive and accurate quantitation of hepatitis B virus DNA using a kinetic fluorescence detection system (TaqMan PCR). J Virol Methods 85: 75-82, 2000

10. Ruan P, Zhou B, Dai X, Sun Z, Guo X, Huang J and Gong Z: Predictive value of intrahepatic hepatitis B virus covalently closed circular DNA and total DNA in patients with acute hepatitis B and patients with chronic hepatitis B receiving anti-viral treatment. Mol Med Rep 9: 1135-1141, 2014.

11. Belloni L, Allweiss L, Guerrieri F, Pediconi N, Volz T, Pollicino T, Petersen J, Raimondo G, Dandri M and Levrero M: IFN- $\alpha$ inhibits HBV transcription and replication in cell culture and in humanized mice by targeting the epigenetic regulation of the nuclear cccDNA minichromosome. J Clin Invest 122: 529-537, 2012.

12. Chou YC, Jeng KS, Chen ML, Liu HH, Liu TL, Chen YL, Liu YC, Hu CP and Chang C: Evaluation of transcriptional efficiency of hepatitis B virus covalently closed circular DNA by reverse transcription-PCR combined with the restriction enzyme digestion method. J Virol 79: 1813-1823, 2005.

13. Fujimoto A, Totoki Y, Abe T, Boroevich KA, Hosoda F, Nguyen $\mathrm{HH}$, Aoki M, Hosono $\mathrm{N}$, Kubo M, Miya F, et al: Whole-genome sequencing of liver cancers identifies etiological influences on mutation patterns and recurrent mutations in chromatin regulators. Nat Genet 44: 760-764, 2012.

14. Li WY, Zeng X, Lee NP, Liu X, Chen S, Guo B, Yi S, Zhuang X, Chen F, Wang G, et al: HIVID: An efficient method to detect HBV integration using low coverage sequencing. Genomics 102: 338-344, 2013

15. Li X, Zhang J, Yang Z, Kang J, Jiang S, Zhang T, Chen T, Li M, Lv Q, Chen X, et al: The function of targeted host genes determines the oncogenicity of HBV integration in hepatocellular carcinoma. J Hepatol 60: 975-984, 2014.

16. Ding D, Lou X, Hua D, Yu W, Li L, Wang J, Gao F, Zhao N, Ren G, Li L and Lin B: Recurrent targeted genes of hepatitis B virus in the liver cancer genomes identified by a next-generation sequencing-based approach. PLoS Genet 8: e1003065, 2012.

17. Bohne F, Chmielewski M, Ebert G, Wiegmann K, Kürschner T, Schulze A, Urban S, Krönke M, Abken H and Protzer U: T cells redirected against hepatitis $B$ virus surface proteins eliminate infected hepatocytes. Gastroenterology 134: 239-247, 2008.
18. Krebs K, Böttinger N, Huang LR, Chmielewski M, Arzberger S, Gasteiger G, Jäger C, Schmitt E, Bohne F, Aichler M, et al: $\mathrm{T}$ cells expressing a chimeric antigen receptor that binds hepatitis B virus envelope proteins control virus replication in mice. Gastroenterology 145: 456-465, 2013

19. Díaz-Montero CM, Naga O, Zidan AA, Salem ML, Pallin M, Parmigiani A, Walker G, Wieder E, Komanduri K, Cole DJ, et al: Synergy of brief activation of CD8 T-cells in the presence of IL-12 and adoptive transfer into lymphopenic hosts promotes tumor clearance and anti-tumor memory. Am J Cancer Res 1: 882-896, 2011

20. Vemuru RP, Aragona E and Gupta S. Analysis of hepatocellular proliferation: study of archival liver tissue is facilitated by an endogenous marker of DNA replication. Hepatology 16: 968-973, 1992 .

21. Hagen TM, Huang S, Curnutte J, Fowler P, Martinez V, Wehr CM, Ames BN and Chisari FV: Extensive oxidative DNA damage in hepatocytes of transgenic mice with chronic active hepatitis destined to develop hepatocellular carcinoma. Proc Natl Acad Sci USA 91: 12808-12812, 1994.

22. Mason WS, Jilbert AR and Summers J: Clonal expansion of hepatocytes during chronic woodchuck hepatitis virus infection. Proc Natl Acad Sci USA 102: 1139-1144, 2005

23. Mason WS, Liu C, Aldrich CE, Litwin S and Yeh MM: Clonal expansion of normal-appearing human hepatocytes during chronic hepatitis B virus infection. J Virol 84: 8308-8315, 2010 .

24. Mason WS, Low CL, Xu C, Aldrich CE, Scougall CA, Grosse A, Clouston A, Chavez D, Litwin S, Peri S, et al: Detection of clonally expanded hepatocytes in chimpanzees with chronic hepatitis B virus infection. J Virol 83: 8396-8408, 2009.

25. Volz T, Lutgehetmann M, Wachtler P, Jacob A, Quaas A, Murray JM, Dandri $M$ and Petersen J: Impaired intrahepatic hepatitis B virus productivity contributes to low viremia in most $\mathrm{HBeAg}$-negative patients. Gastroenterology 133: $843-852,2007$.

26. Nguyen T, Thompson AJ, Bowden S, Croagh C, Bell S, Desmond PV, Levy M and Locarnini SA: Hepatitis B surface antigen levels during the natural history of chronic hepatitis B: A perspective on Asia. J Hepatol 52: 508-513, 2010.

27. Thompson AJ, Nguyen T, Iser D, Ayres A, Jackson K, Littlejohn M, Slavin J, Bowden S, Gane EJ, Abbott W, et al: Serum hepatitis B surface antigen and hepatitis B e antigen titers: Disease phase influences correlation with viral load and intrahepatic hepatitis B virus markers. Hepatology 51: 1933-1944, 2010.

28. Manesis EK, Papatheodoridis GV, Tiniakos DG, Hadziyannis ES, Agelopoulou OP, Syminelaki T, Papaioannou C, Nastos T and Karayiannis P: Hepatitis B surface antigen: Relation to hepatitis $\mathrm{B}$ replication parameters in $\mathrm{HBe} \mathrm{Ag}$-negative chronic hepatitis B. J Hepatol 55: 61-68, 2011.

29. Bonilla Guerrero R and Roberts LR: The role of hepatitis B virus integtation in the pathogenesis of human hepatocellular carcinoma. J Hepatol 42: 760-777, 2005. 